\section{(a)}

\section{Revista Mexicana de Ciencias Forestales}

ISSN: 2007-1132

ciencia.forestal2@inifap.gob.mx

Instituto Nacional de Investigaciones

Forestales, Agrícolas y Pecuarias

México

García Cuevas, Xavier; Rodríguez Santiago, Bartolo; Islas Gutiérrez, Juan

Evaluación financiera de plantaciones forestales de caoba en Quintana Roo

Revista Mexicana de Ciencias Forestales, vol. 2, núm. 7, septiembre-octubre, 2011, pp. 7-

26

Instituto Nacional de Investigaciones Forestales, Agrícolas y Pecuarias

Distrito Federal, México

Disponible en: http://www.redalyc.org/articulo.oa?id=63438963002

Cómo citar el artículo

- Número completo

- Más información del artículo

- Página de la revista en redalyc.org

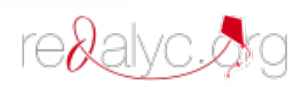

Sistema de Información Científica

Red de Revistas Científicas de América Latina, el Caribe, España y Portugal Proyecto académico sin fines de lucro, desarrollado bajo la iniciativa de acceso abierto 


\title{
EVALUACIÓN FINANCIERA DE PLANTACIONES FORESTALES DE CAOBA EN QUINTANA ROO
}

\author{
FINANCIAL ASSESSMENT OF MAHOGANY FOREST PLANTATIONS IN QUINTANA ROO STATE
}

\author{
Xavier García Cuevas', Bartolo Rodríguez Santiago y y Juan Islas Gutiérrez²
}

\section{RESUMEN}

Las plantaciones forestales en México no han tenido resultados de acuerdo al esfuerzo y recursos invertidos en ellas. El problema fundamental es que no se les ha dado el seguimiento requerido, en virtud de que el éxito de los programas actuales debe medirse por el porcentaje de supervivencia en el campo, así como por el crecimiento y rendimiento de madera y no por el número de plantas que se producen en los viveros. Además, para hacer de las plantaciones forestales una actividad económica rentable, es necesario proporcionar apoyos a los productores, a través del Gobierno Federal y la banca nacional. Bajo este contexto, el presente trabajo se realizó con datos obtenidos en el centro y sur de Quintana Roo, en los municipios de José María Morelos, Felipe Carrillo Puerto y Otón Pompeyo Blanco. La información recopilada es de tipo financiero (costos y beneficios ha ${ }^{-1}$ ) e indicadores financieros para plantaciones forestales comerciales, entre los que destacan: VPN = 162,344.2, TIR = 13.37 y $B / C=4.10$, que les servirán a los productores y financiadores en el proceso de toma de decisiones. Finalmente, se analizan y discuten los indicadores financieros y el análisis de sensibilidad sobre su rentabilidad. Los resultados indican que las plantaciones pueden ser un buen negocio en Quintana Roo.

Palabras clave: Análisis financiero, caoba, plantaciones forestales comerciales, productores forestales, rentabilidad, sensibilidad.

\begin{abstract}
Forest plantations operations in Mexico have not produced results according to the efforts and resources invested in them. The main problem is that they have not received the necessary follow-up as the success of the existing programs should be measured by the per cent of survival in the field, as well as its growth and wood yield and not by the number of plants produced in the nursery. In addition, to make a profitable business out of forest plantations support must be provided to producers, in which the Federal Government and the national banks should be involved. In this context, this work was carried out with information from the Centre and South of Quintana Roo State, in the municipalities of José María Morelos, Felipe Carrillo Puerto and Othon Pompeyo Blanco. Financial information is presented (benefits, cost / ha $\mathrm{a}^{-1}$ ) and financial indicators obtained for commercial forest plantations), being among the most important: VPN $=162,344.2, T I R=13.37$ and $B / C=4.10$, which will be used to support producers and funders to make decisions. Finally, the financial indicators and the sensitivity on the profitability of forest plantations are analyzed and discussed. These results indicate that plantations can be an attractive business in Quintana Roo, México.
\end{abstract}

Key words: Financial analysis, mahogany, commercial forest, forest producers, profitability, sensitivity.

Fecha de recepción: 17 de marzo de 2010.

Fecha de aceptación: 10 de junio de 2011.

\footnotetext{
${ }^{1}$ Campo Experimental Chetumal. CIR-SE INIFAP. Correo- e: garcia.xavier@inifap.gob.mx
}

${ }^{2}$ Campo Experimental Valle de México. CIR-CE INIFAP. 


\section{INTRODUCAÓN}

En el Inventario Nacional Forestal Periódico de 1992 - 1994, se consigna que el total de la superficie del territorio nacional ( 196 millones ha) 29 \% cuenta con cobertura forestal arbolada (selvas y bosques) y 43 \% con vegetación de zonas áridas y vegetación de áreas con disturbio las cuales están amenazadas por la constante pérdida de superficie arbolada de bosques templados y selvas tropicales (FUMIAF, 2005a).

La deforestación se ha agudizado, dramáticamente, en las cuatro últimas décadas, pues sus cifras oscilan entre 370,000 y 746,000 ha por año. Las tasas de deforestación más altas se presentan en los estados de Veracruz y Tabasco y en el Distrito Federal, en donde desde 1973 se pierden cada año entre el 1 y $2 \%$ de la cubierta vegetal (FUMIAF, 2005a).

Para revertir este problema, durante muchos años el Gobierno Federal en México siguió la política del establecimiento de plantaciones forestales, aunque limitada, principalmente, a la reforestación para protección de áreas degradadas (Del Castillo, 1996).

Ante la alarmante situación, en 1997 la Comisión Nacional Forestal (CONAFOR) a través de la Gerencia de Desarrollo de Plantaciones Forestales Comerciales de la Coordinación General de Producción y Productividad implementó y puso en marcha el Programa para el Desarrollo de Plantaciones Forestales Comerciales (PRODEPLAN), el cual fue rediseñado en el 2001. El objetivo general del PRODEPLAN consiste en brindar apoyos financieros directos con un monto total de hasta $75 \%$ de los costos de establecimiento y mantenimiento, durante los primeros 7 años de edad, para alcanzar una meta de 875,000 ha de plantaciones forestales comerciales en el año 2025. Lo anterior, con el fin de reducir las importaciones de productos forestales y de crear alternativas de desarrollo sustentable y diversificación productiva en México, mediante la reconversión al uso forestal de terrenos que alguna vez fueron desmontados con fines agropecuarios (COFOM, 2003; FUMIAF, 2005a, 2005b).

A partir de las acciones descritas, las plantaciones comerciales de especies forestales han aumentado de manera considerable en los últimos tiempos, en diversos estados de la República Mexicana. El PRODEPLAN financió 1,572 proyectos de 1997 al 2004, con una inversión total de $\$ 1,820$ '033,636.76 y en una superficie de 303,036.64 ha, de las cuales 92,888.26 ha correspondieron a cedro rojo (Cedrela odorata L.) y 37,975 ha a caoba (Swietenia macrophylla King) asociadas con otras maderas preciosas; para ello la CONAFOR aportó un total de $\$ 601$ '084,413. 15 para la primera especie y $\$ 243$ '882,892.29 para la segunda (FUMIAF, 2005a, 2005b).

\section{INTRODUCTION}

In the 1992 - 1994 Periodical National Forest Inventory is reported that $29 \%$ of the total national territory ( 196 million ha) is covered by trees (of tropical and temperate forests) and $43 \%$ by arid vegetation and vegetation of disturbed areas, and that it is threatened by the constant loss of tree area of mild-weather forests and tropical forests (FUMIAF, 2005a).

Deforestation has dramatically worsened in the last four decades, as their numbers are between 370,000 and 746,000 ha per year. The highest deforestation rates occur at the states of Veracruz and Tabasco and in Distrito Federal, where every year since 1973 is lost from 1 to $2 \%$ of the green cover (FUMIAF, 2005a).

To revert this problem, during many years the Federal Government of Mexico applied the policy of establishing forest plantations, though limited, mainly, to reforestation in order to protect degraded areas (Del Castillo, 1996).

Facing this alarming situation, in 1997 the National Forest Commission (CONAFOR) through the Commercial Forest Plantation Development Office of the General Coordination of Production and Productivity started the Program for the Development of Commercial Forest Plantations (PRODEPLAN), which was reformulated in 2001. The general aim of PRODEPLAN consists in directly providing financial support up to 75 per cent of the costs of establishment and maintenance during the first 7 years, to reach a goal of 875,000 ha of commercial forest plantations in 2025. This is meant to reduce forest products imports and to create sustainable development alternatives and productive diversification in Mexico, by reversing deforested lands for agriculture endings to forest use (COFOM, 2003; FUMIAF, 2005a, 2005b).

Starting from the formerly described actions, commercial plantations of forest species have increased considerable in recent times, in several states of the country. PRODEPLAN sponsored 1,572 projects from 1997 to 2004 with a total investment of $\$ 1,820^{\prime} 033,636.76$ over 303,036.64 ha, of which $92,888.26$ ha were of red cedar (Cedrela odorata L.) and 37,975 ha of mahogany (Swietenia macrophylla Kingl associated with other precious woods species, thus, CONAFOR submitted a total amount of $\$ 601$ '084,413.15 for the first species and $\$ 243$ '882,892.29 for the second (FUMIAF 2005a, 2005b).

In every productive activity of the primary sector, of new creation or an extension of those that already exist, there will always be the need to know in advance the behavior of the variables that positively or negatively impact their 
En toda actividad productiva del sector primario, sea de nueva creación o de ampliación de las existentes, se tendrá siempre la necesidad de conocer con anticipación el comportamiento de las variables que impactan positiva o negativamente su desarrollo. Para ello, se requieren estrategias de estudio que permitan el análisis de las distintas variables que pueden afectarlas, y en consecuencia, contar con el personal capacitado para su ejecución (UV, 2007).

\section{Definición de proyecto de inversión}

Un proyecto de inversión es una propuesta técnico-económica para la solución de una necesidad actual o futura, a partir de los recursos disponibles ahora o en el futuro (INTECPLAN, 2007). También se puede definir como una propuesta escrita de acción técnico-económica que se le asigna un monto de capital para resolver una necesidad, mediante un conjunto de recursos disponibles (humanos, materiales y tecnológicos). En el documento debe haber una serie de estudios que le permitan al inversionista tener la idea clara, y a las instituciones que lo apoyan saber si la propuesta es viable y dará ganancias (BANOBRAS, 2005; Graterol, 2008).

\section{Inversión en proyectos forestales}

El desarrollo rural sostenible es una preocupación importante de los gobiernos y de las agencias internacionales. No obstante que las tierras de vocación forestal dominan gran parte del territorio de los países de América Latina y el Caribe, no son una fuente de prosperidad para las áreas marginadas, por lo que han sido objeto de destrucción, con graves consecuencias económicas, sociales y ambientales (BID, 2005).

Existen muchos factores que contribuyen a crear un clima desfavorable a los negocios forestales, como por ejemplo: modestas capacidades técnicas, financieras y comerciales de los propietarios y empresarios locales; carencia de información; políticas e incentivos gubernamentales adversos lincertidumbres de la tenencia de la tierra, restricciones comerciales, deficiente marco legal, cambios de uso de suelo, etc.) (BID, 2005).

En Latinoamérica, las inversiones directas a la actividad forestal son importantes fuentes de financiamiento en algunos países como Brasil y Chile, en donde las plantaciones forestales constituyen un elemento fundamental de sus estrategias de desarrollo socioeconómico. En dichos países, este tipo de inversiones son motores que impulsan las economías y contribuyen a que la sociedad prospere (BID, 2005).

Las evidencias indican que la inversión directa en actividades sostenibles de la cadena productiva forestal favorece el development. Thus, study strategies that allow the analysis of different variables that can be affected are required, and consequently, to count with the trained personnel for their accomplishment (UV, 2007).

\section{Investment project definition}

An investment project is a technical-economic proposal for the solution of a present or future need (INTECPLAN, 2007). It can also be defined as a written proposal of technical-economic action to which an amount of money is assigned to solve some need, through a group of available resources (human, material and technologicall. The document should include a series of studies that allow the investor to have a clear idea, and to the institutions that support him, if the proposal is viable and will be profitable (BANOBRAS, 2005; Graterol, 2008).

\section{Investment in forest projects}

The rural sustainable development is an important concern for governments and international agencies. In spite of the fact that lands with forest vocation are dominant in great part of the territories of Latin American and Caribbean countries, they are not a source of prosperity for marginal areas, thus becoming objects of destruction with severe economic, social and environmental consequences (BID, 2005).

There are many factors that help to create an unfavorable environment for forest businesses, such as: modest technical, financial and commercial abilities of the local owners and businessmen; lack of information; adverse governmental policies and incentives (uncertainty in land-ownership, commercial restrictions, deficient legal framework, changes in land-use, etc.) (BID, 2005).

In Latin America, direct investments to the forest activity are important sponsoring sources in some countries like Brazil and Chile, where forest plantations constitute a basic element of their socio-economical development strategies. In those countries, this kind of investments are driving forces that promote economies and help society to prosper (BID, 2005).

Evidence shows that direct investment in sustainable activities of the forest productive chain favors increments in production, productivity and competitiveness of the sector, as well as job generation, income, foreign currency, elimination of poverty and the improvement of the environment. The level of investment depends on the situation that investors face and that influence the success and profitability of their business. In order to make of them substantial sources of financial, technical and commercial resources for the sustainable forest development of the countries, it is necessary to have detailed studies of the factors involved, to compare, analyze and identify formulae that help to their feasibility (BID, 2005). 
incremento en la producción, productividad y la competitividad del sector; así como a la generación del empleo, ingreso, la obtención de divisas, el abatimiento de la pobreza y el mejoramiento del ambiente. El nivel de inversiones depende de las condiciones que los inversionistas enfrentan y que inciden en el éxito y la rentabilidad de sus negocios. Para que estas constituyan una fuente significativa de recursos financieros, técnicos y comerciales para el desarrollo forestal sostenible de los países, se requieren estudios detallados de los factores que en ellos intervienen, para poder hacer comparaciones, análisis e identificar fórmulas eficaces que contribuyan a su factibilidad (BID, 2005).

En las últimas décadas, en los países en desarrollo se tiene una idea cada vez más clara de la contribución de las inversiones forestales en el avance económico, social y ambiental, por lo que algunas naciones han decidido aumentar la financiación del sector forestal, pero otras no tienen los recursos necesarios para promoverlos. Por su parte, los organismos internacionales de financiación han aumentado su asignación de fondos al sector, pero las cantidades involucradas siguen siendo pequeñas en comparación con las necesidades de inversión en la silvicultura, y los técnicos forestales no han sido capaces de convencer a las autoridades de su importancia (McGaughey, 2007).

\section{Plantaciones forestales comerciales en México}

En la década de los años cincuenta se hizo un gran esfuerzo para establecer plantaciones forestales con fines comerciales; tal fue el caso de la empresa FIBRACEL S. A., en Tamuín, San Luís Potosí, que plantó 6,400 ha de Eucalyptus spp. para producir madera destinada a la fabricación de tableros aglomerados. Otra experiencia interesante fue FAPATUX S. A., en la región de La Sabana, en Oaxaca, que entre 1974 y 1980 plantó 10,000 ha con Pinus caribaea Morelet destinadas a la obtención de materia prima para celulosa y papel (PRODEFO, 2000).

A partir del año 2000 el PRODEPLAN adquiere el rango de decreto presidencial, lo que asegura su continuidad hasta el logro de los objetivos planteados en el año 2025. El propósito del PRODEPLAN es apoyar, a lo largo de 25 años, el establecimiento de 875,000 ha de plantaciones forestales comerciales, a fin de reducir las importaciones de productos forestales y al mismo tiempo crear alternativas de desarrollo sustentable y diversificación productiva en México. Se espera para el final del periodo considerado, el total de las superficies plantadas entren en producción (COFOM, 2003).

De acuerdo con datos de la CONAFOR, de 1997 a 2006 se plantaron 71 mil ha y de 2007 a 2012 se estima se establecerán 224 mil ha. Para 2009 se citan más de 110 mil ha de plantaciones forestales con fines comerciales, principalmente de eucalipto (Eucalyptus grandis W. Hill, Eucalyptus urophylla S.
In the last decades, in the developing countries, there is a more clear idea of the involvement that forest investments have in the economic, social and environmental progress, which has encouraged some nations to increase financial support to the forest sector, though some do not count with enough resources to promote it. On the other hand, international financial agencies have increased their funding to the sector, but the amounts are still small compared to the investment needs of forestry and forest technicians have not been able to convince their authorities of its importance (McGaughey, 2007).

\section{Commercial forest plantations in Mexico}

In the 50's a great effort was made to establish forest plantations with commercial purposes; such was the case of FBRACEL S. A. company, in Tamuín, San Luís Potosí State, which planted 6,400 ha of Eucalyptus spp. to get wood to produce particle boards. Another interesting experience was with FAPATUX S. A., in the La Sabana region, Oaxaca State, that between 1974 and 1980 planted 10, 000 ha with Pinus caribaea Morelet to have raw material for cellulose and paper pulp (PRODEFO, 2000).

In 2000, PRODEPLAN was raised to the presidential decree level, which guarantees its permanence till the accomplishments of its goals in the year 2025. The aim of PRODEPLAN is to support, during 25 years, the establishment of 875,000 ha of commercial forest plantations in order to reduce forest products imports, and, at the same time, to create options for sustainable development and productive diversification in Mexico. It is expected that by the end of the period the planted areas become productive (COFOM, 2003).

According to CONAFOR, from 1997 to 2006, 71 thousand ha were planted and from 2007 to 2012, 224 thousand ha are estimated to be planted as well. For 2009 are stated more than 110 thousand ha of forest commercial forest plantations, mainly of Eucalyptus grandis W. Hill, Eucalyptus urophylla S. T. Blake, cedar (Cedrela odorata), melina (Gmelina arborea Roxb., pine (Pinus sp.), mahogany (Swietenia macrophylla), teca (Tectona grnadis L. f.) among other species (Figure 1). The greatest part of the area for this ending (80\%) is located in the States of Tabasco, Veracruz, Campeche and Oaxaca (Noguez, 2010). Ten are the main planting companies, most of which are found in the South and Southeast of the country (Table 1) (Monreal, 2007).

At a national scale, the federal government has sponsored 3,629 projects in the last últimos 10 years, which means more than 530 mil ha, to which 3,679 million pesos have been oriented (Noguez, 2010). 
T. Blake), cedro (Cedrela odorata), melina (Gmelina arborea Roxb., pino (Pinus sp.), caoba (Swietenia macrophylla), teca (Tectona grnadis L. f.) entre otras especies (Figura 1). La mayor parte de la superficie destinada a este propósito (80\%) se ubica en los estados de Tabasco, Veracruz, Campeche y Oaxaca (Noguez, 2010). Son diez las principales empresas plantadoras, la mayor parte de ellas se ubican en el sur y sureste del país (Cuadro 1), (Monreal, 2007).

A nivel nacional, el gobierno federal ha financiado 3,629 proyectos en los últimos 10 años, lo que significa una superficie de más de 530 mil hectáreas, a las que se han destinado 3,679 millones de pesos (Noguez, 2010).

En 2002 se inició, en México, la producción de materias primas provenientes de plantaciones forestales comerciales con apoyos federales; ese año la producción maderable fue de 100 mil m³ y en 2007 esta cifra se elevó a 350 mil m. Se espera que en el periodo de 2007 a 2012 la producción maderable de dicho origen llegue a 5 millones de $\mathrm{m}^{3}$. Actualmente, la producción maderable nacional (de bosques naturales y plantaciones) es de alrededor de 7 millones $\mathrm{m}^{3}$ año $^{-1}$ (Noguez, 2010).

No obstante que las plantaciones establecidas tienen pronósticos alentadores, hay poca información confiable de su productividad, rentabilidad o de su adaptación a diferentes sitios y regímenes de manejo (Synnott, 2005), por lo que existe la necesidad de analizar la conveniencia de invertir capital financiero para su explotación, con un grado alto de éxito en la implementación de los proyectos (FUMIAF, 2005b).

Por lo anterior el objetivo de este trabajo es determinar la rentabilidad financiera de plantaciones forestales de caoba para la producción de madera en rollo en Quintana Roo.

\section{MATERIALES Y MÉTODOS}

\section{Descripción del área de estudio}

En los municipios de José María Morelos y Othón Pompeyo Blanco, Quintana Roo se localiza la mayor parte de los suelos de Rendzinas (Figura 2a), que son los mejores del estado y los más apropiados para el establecimiento de cultivos agrícolas o forestales (SARH, 1981; $\mathbb{N E G l , ~ 1 9 8 6 ) . ~}$ Muchos de esos terrenos fueron desmontadas con fines agrícolas o ganaderos en la década de los setentas, pero en la actualidad son tierras ociosas aptas para el establecimiento de plantaciones forestales con fines comerciales, en ellas se localizan más de 2,500 ha de cedro y caoba.

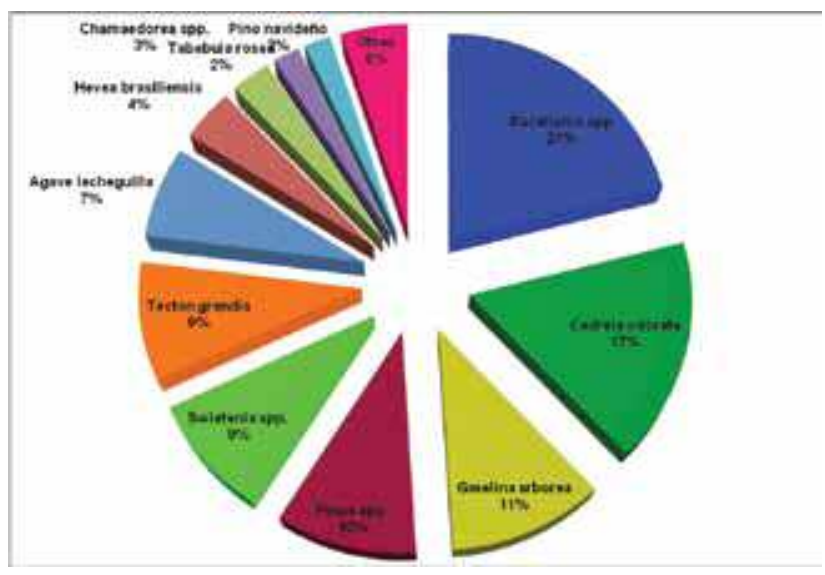

Fuente: Monreal, 2007.

Source: Monreal, 2007.

Figura 1. Principales especies forestales usadas en plantaciones forestales comerciales en México.

Figure 1. Main forest species used in commercial forest plantations in Mexico.

In 2002 started in Mexico, raw material production from comercial forest plantations with federal funding; timber production that year was $100 \mathrm{mil} \mathrm{m}^{3}$ and in 2007, that number rose to 350 thousand $\mathrm{m}^{3}$. It is expected that for the 2007 - 2012 period, timber production from that origin might reach 5 million $\mathrm{m}^{3}$. At present, the national production of wood (from natural forests and plantations) is around 7 million $\mathrm{m}^{3}$ year ${ }^{-1}$ (Noguez, 2010).

In spite of the stimulating forecasts that the established plantations have, there is scarce reliable information about their productivity, profitability or their adaptation to different sites and management regimes (Synnott, 2005), as there exists the need to analyze the convenience of investing financial capital for their exploitation with a rather high degree of success in the implementation of projects (FUMIAF, 2005b).

Based upon the former arguments, the aim of this study is to determine the financial profitability of mahogany forest plantation to produce roundwood in the State of Quintana Roo.

\section{MATERIALS AND METHODS}

\section{The study area}

In José María Morelos and Othón Pompeyo Blanco municipalities in Quintana Roo State, are located the greatest part of Rendzinas soils (Figure 2a), which are the best in the State and the most fit for the establishment of crops and forests (SARH, 1981; INEGI, 1986). In many of these lands trees were removed with agricultural or grazing endings during the 70's, 
Cuadro 1. Principales proyectos de plantaciones forestales comerciales que se desarrollan en México.

Table 1. Major projects of commercial forest projects that are taking place in Mexico.

\begin{tabular}{|c|c|c|c|c|}
\hline Nombre & Ubicación & Superficie plantada & Especie & $\begin{array}{l}\text { Finalidad } \\
\text { productiva }\end{array}$ \\
\hline $\begin{array}{l}\text { PROPLANSE-DESARROLLO } \\
\text { FORESTAL }\end{array}$ & $\begin{array}{l}\text { Sur de Veracruz, oriente } \\
\text { de Tabasco; Michoacán } \\
\text { y México } \\
\text { Occidente de Tabasco }\end{array}$ & $\begin{array}{l}6,500 \text { ha (2006); } \\
10 \text { mil (2012) }\end{array}$ & \multirow{14}{*}{$\begin{array}{l}\text { Eucaliptos (E. grandis y } \\
\text { E. urophylla) } \\
\text { Eucaliptos (E. grandis } \\
\text { y E. urophylla), melina } \\
\text { (Gmelina arborea) } \\
\text { Melina (Gmelina } \\
\text { arborea) y teca } \\
\text { (Tectona grandis) } \\
\text { Teca (Tectona grandis) } \\
\text { y cedro (Cedrela } \\
\text { odorata) } \\
\text { Eucaliptos (E. grandis y } \\
\text { E. urophylla) } \\
\text { Eucalipto grande } \\
\text { (E. grandis) y Hule } \\
\text { (Hevea brasiliensis } \\
\text { (Willd.ex Adr. Juss.)Arg.) } \\
\text { Eucaliptos (E. grandis y } \\
\text { E. urophylla) } \\
\text { Melina (Gmelina } \\
\text { arborea) } \\
\text { Melina (Gmelina } \\
\text { arborea) y otras } \\
\text { Cedro rosado } \\
\text { (Acrocarpus } \\
\text { fraxinifolius Wighit. \& } \\
\text { Arn.) }\end{array}$} & \multirow{14}{*}{$\begin{array}{c}\text { Tableros de } \\
\text { madera y } \\
\text { celulosa } \\
\text { Madera } \\
\text { aserrada (pisos) y } \\
\text { celulosa } \\
\text { Madera } \\
\text { aserrada } \\
\text { (muebles) } \\
\text { Madera } \\
\text { aserrada } \\
\text { (muebles) } \\
\text { Celulosa; madera } \\
\text { aserrada y } \\
\text { tableros } \\
\text { Látex, celulosa y } \\
\text { madera aserrada } \\
\\
\text { Celulosa } \\
\\
\text { Madera } \\
\text { aserrada } \\
\text { (muebles) } \\
\text { Madera } \\
\text { aserrada } \\
\text { (muebles) } \\
\text { Madera } \\
\text { aserrada } \\
\text { (muebles) }\end{array}$} \\
\hline SILTROMEX Y OTRAS & $\begin{array}{l}\text { Sur de Veracruz y } \\
\text { Campeche }\end{array}$ & 5 mil ha (2006); & & \\
\hline \multirow[t]{2}{*}{ AGSA } & Noroeste de Campeche & 4 mil ha (2006); & & \\
\hline & \multirow{2}{*}{$\begin{array}{l}\text { Norte de Oaxaca y sur } \\
\text { de Veracruz }\end{array}$} & $\begin{array}{l}10 \text { mil ha (2012) } \\
2,600 \text { ha (2006); }\end{array}$ & & \\
\hline PLANTEH & & 10 mil ha (2012) & & \\
\hline \multirow[t]{2}{*}{ FORESTALES MEXICANOS } & \multirow[t]{2}{*}{ Oriente de Tabasco } & 2,500 ha (2006); & & \\
\hline & & 5 mil ha (2012) & & \\
\hline \multirow[t]{2}{*}{ SILVICULTURA SARAYA } & \multirow{2}{*}{$\begin{array}{l}\text { Costa grande de } \\
\text { Guerrero }\end{array}$} & 2,300 ha (2006); & & \\
\hline & & 6 mil has (2012) & & \\
\hline $\begin{array}{l}\text { FORESTAL } \\
\text { HERMANOS }\end{array}$ & El Carmen, Campeche & 3 mil ha (2010) & & \\
\hline \multirow[t]{2}{*}{ PROFORCA } & \multirow[t]{2}{*}{ Centro de Campeche } & 1,000 ha (2006); & & \\
\hline & & 2 mil ha (2012) & & \\
\hline \multirow{2}{*}{$\begin{array}{l}\text { A G R OF OR E S T A L } \\
\text { TEPONAXTLE }\end{array}$} & \multirow{2}{*}{$\begin{array}{l}\text { Límites entre Puebla y } \\
\text { Veracruz }\end{array}$} & 1,000 ha (2006); & & \\
\hline & & 2 mil ha (2012) & & \\
\hline
\end{tabular}

Fuente: Monreal (2007).

Source: Monreal (2007).

En estos lugares, la precipitación promedio anual es de alrededor de 1,200 mm, con una época seca entre los meses de diciembre y mayo. La temperatura media anual es de $27^{\circ} \mathrm{C}$ y las mínimas y máximas de 20 y $34^{\circ} \mathrm{C}$. Predominan los climas Aw(x')i, o cálido subhúmedo con lluvias en verano y parte del invierno, con oscilación de la temperatura menor a $5{ }^{\circ} \mathrm{C}$. Se localiza en el sureste del estado, en regiones del Río Hondo, Bacalar y X-Calak. El clima Awi (X) g, o cálido subhúmedo con medianas lluvias de verano y escasa en invierno, con oscilación térmica mayor de $7^{\circ} \mathrm{C}$. y se ubica en la región centro-noreste del estado y el $\mathrm{Aw}_{2}$ (i) o cálido subhúmedo con abundantes lluvias en verano y oscilación térmica entre 5 y $7{ }^{\circ} \mathrm{C}$ domina en la mayor parte de la entidad (SARH, 1981; INEGI, 1986). but at present are idle lands suitable for the establishment of commercial forest plantations, where 2,500 ha more of mahogany and red cedar are found.

In these places, the annual average precipitation is around 1,200 mm, with a dry season between December and May. The annual average temperature is $27^{\circ} \mathrm{C}, 20^{\circ} \mathrm{C}$ the minimal and $34^{\circ} \mathrm{C}$ the maximal. The $\mathrm{Aw}\left(\mathrm{x}^{\prime}\right) \mathrm{i}$, or semi-humid warm climate with Summer and part of Winter rain, with an oscillation under $5^{\circ} \mathrm{C}$ prevail. It is found at the Southeast of the State, in the Río Hondo, Bacalar on X-Calak regions. The Awi $(X) \mathrm{g}$, or, with medium rains during Summer and scarce in Winter, with a thermical oscillation over $7^{\circ} \mathrm{C}$ and is present in the Northeastern-central region of the State, and the $\mathrm{Aw}_{2}$ (i) or subhumid warm climate with heavy rains during Summer and a thermical oscillation between 5 and $7{ }^{\circ} \mathrm{C}$, which dominates most of the State (SARH, 1981; INEGI, 1986). 
La superficie es casi plana con suave e inapreciable inclinación de sur a norte y su elevación máxima se presenta en la región de X-Pujil. Los suelos predominantes, clasificados en series de acuerdo a la terminología maya, corresponden a la serie Tzek'El (Litosol), muy abundantes en el centro y norte del estado, se localizan en las partes altas y quebradas del terreno, constituidos por rocas fragmentadas de gran y regular tamaño y los suelos se observan en las fisuras de las rocas calcáreas, y su profundidad es inferior a $15 \mathrm{~cm}$. La serie Puslum (Rendzina), corresponde a tierra suelta con piedras; son suelos negros o café muy obscuro, pedregosos y con profundidad menor a $40 \mathrm{~cm}$, yacen sobre roca caliza, con drenaje interno superficial muy rápido y fácilmente erosionables (SARH, 1981; INEGI, 1986), (Figura 2a).

El tipo de vegetación predominante es selva mediana subperennifolia (Figura 2b), cuyos componentes son árboles de 15 a 30 m y las especies características: ramón (Brosimun alicastrum Sw.), chaká (Bursera simaruba (L.) Sarg.), chicozapote (Manilkara sapota (L.) Van Royen), tzalam (Lysiloma latisiliquum (L.) Benth), tajmay (Zuelania guidonia (Sw.) Britt. \& Millsp.), ya'axnik (Vitex gaumeri Greenm.), pukté (Bucida buceras L.) y tabaquillo (Alseis yucatanensis Standl.) (INEGI, 1986).
The surface is almost flat with a soft and unnoticed slope from South to North; its highest elevation is in the X-Puil region. The prevailing soils, classified by series according to the Mayan terminology, belong to the Tzek'El series (Litosol), very abundant in the Center and North of the State, are located in the high and cracked parts of the land, are made-up by fragmented rocks of big and regular size and soils are observed in the cracks of the calcareous rocks; their depth is under $15 \mathrm{~cm}$. The Puslum series (Rendzina) are made up by loose ground with stones; black to very dark -brown soils, rocky and under $40 \mathrm{~cm}$ deep, which lay over limestone, with very fast superficial internal drainage and easily erodible (SARH, 1981; INEGI, 1986) (Figure 2a).

The prevailing type of vegetation is medium sub-evergreen tropical forest (Figure 2b), which has 15 to $30 \mathrm{~m}$ trees and the following are the typical species: ramón (Brosimun alicastrum Sw.), chaká (Bursera simaruba (L.) Sarg.), chicozapote Manilkara sapota (L.) Van Royen), tzalam (Lysiloma latisiliquum (L.) Benth), taimay (Zuelania guidonia (Sw.) Britt. \& Millsp.), ya'axnik (Vitex gaumeri Greenm.), pukté (Bucida buceras L.) and tabaquillo (Alseis yucatanensis Standl.) (INEGI, 1986).

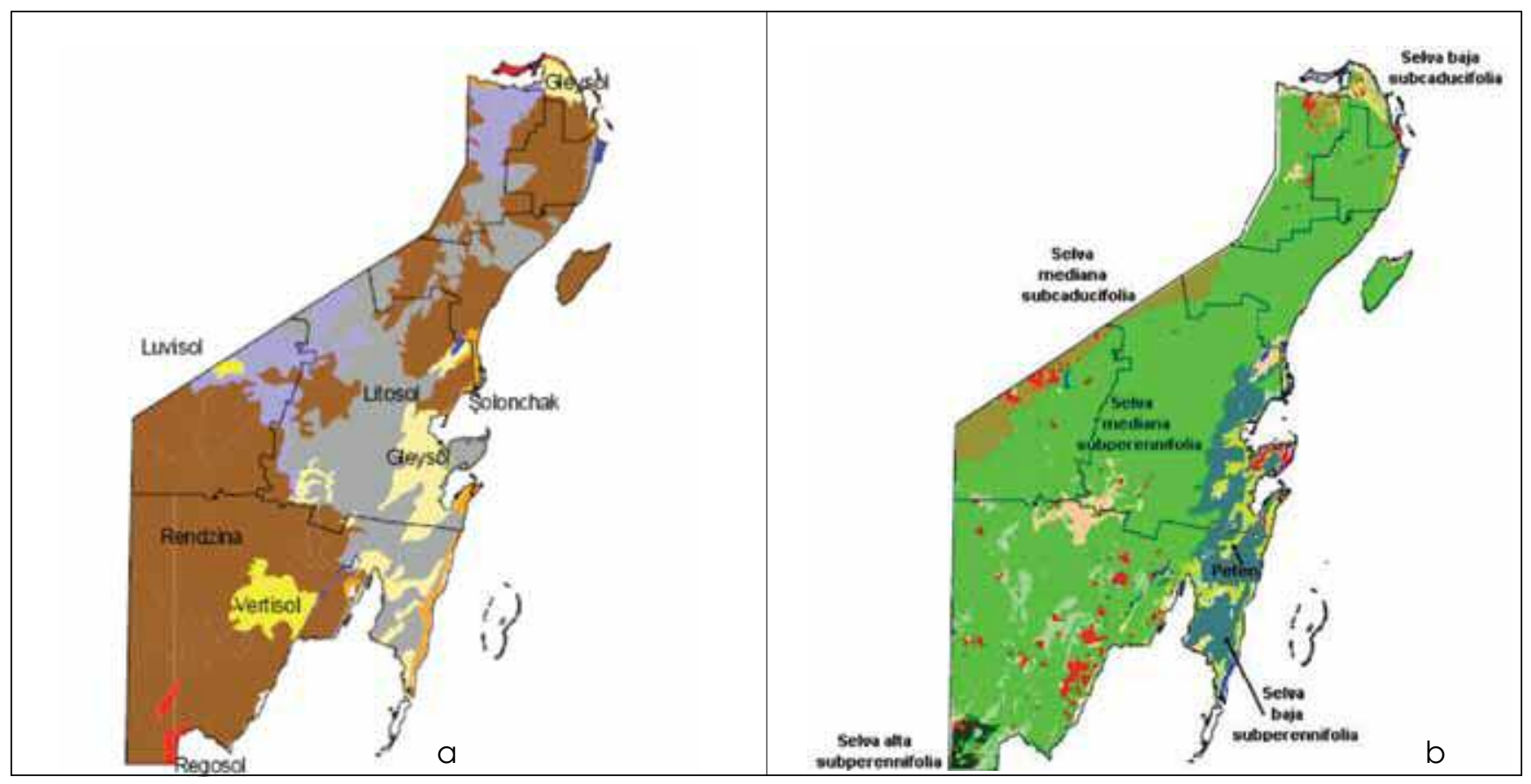

Fuente: http://www.economia.gob.mx/pics/p2757/Sector_Final_QROO.pdf. Source: $h t t p: / / w w w . e c o n o m i a . g o b . m x / p i c s / p / 2757 / S e c t o r$ Final__QROO.pdf.

Figura 2. Distribución de los tipos de suelos y vegetación predominantes en el estado de Quintana Roo. Figure 2. Distribution of the types of prevailing soils and vegetation in Quintana Roo State. 
La selva baja subperennifolia (Figura 2b) se localiza en el sur a la altura de Cozumel, Kantunilkín y las cercanías de Felipe Carrillo Puerto. La conforman individuos de menos de $15 \mathrm{~m}$ de altura y los taxa representativos son: tinto (Haematoxylom campechianum L.), pukté (Bucida buceras), chechem (Metopium brownei (Jaca.) Urban) y sakpai (Byrsonima bucidaefolia Standl.) (INEGI, 1986).

La selva alta subperennifolia (Figura 2b) se distribuye en la parte sur del estado; su estrato arbóreo supera los $30 \mathrm{~m}$ de altura y en él sobresalen: caoba (Swietenia macrophylla), chicozapote (Manilkara zapota), pukté (Bucida buceras), ramón (Brosimun alicastrum), chaka (Bursera simaruba), pimienta (Pimenta dioica (L). Merrill), cedro rojo (Cedrela odorata) y caimito (Chrysophyllum mexicanum T. S. Brandegee ex Standl.) (INEGI, 1986).

Determinación del horizonte de planeación del proyecto

El horizonte de planeación se definió en 30 años, dado que es el tiempo en el cual los ejemplares de caoba alcanzan su turno financiero (García, 1998).

Fuente de información para el análisis financiero

Los coeficientes técnicos de establecimiento y manejo, así como sus precios asociados se obtuvieron de la Unión de Indigenistas Mayas Plantadores Forestales Pa'Ka'Al Malo'O Cheo, S. A de C. V. y del despacho de Servicios Silvoagropecuarios S. A. (SESISA). Las estimaciones de los volúmenes de corta y residuales se realizaron con las funciones de producción y de incrementos ajustadas por García (1998):

$$
\begin{aligned}
& V T H=3.4664 E+0.6286 E^{2}-0.0120 E^{3} \\
& I C A=3.4664+1.2572 E-0.0360 E^{2} \\
& I M A=3.4664+0.6286 E-0.0120 E^{2}
\end{aligned}
$$

Donde:

VTH = Volumen total por hectárea $\left(\mathrm{m}^{3} \mathrm{ha}^{-1}\right)$. ICA = Incremento corriente anual $\left(\mathrm{m}^{3} \mathrm{ha}^{-1}\right.$ año- $\left.\mathrm{o}^{-1}\right)$. IMA = Incremento medio anual $\left(\mathrm{m}^{3} \mathrm{ha}^{-1} \mathrm{año} \mathrm{o}^{-1}\right)$. $E=$ Edad (años).

\section{Indicadores financieros}

Son las medidas del valor de la rentabilidad del proyecto más usadas en la actualidad, puesto que consideran el concepto del "valor del dinero en el tiempo". Estas no son excluyentes entre sí, sino que se pueden usar en forma complementaria para tomar decisiones (Barbosa, 2007). Los indicadores financieros utilizados fueron: el Valor Actual Neto (VAN), Tasa Interna de
The low sub-evergreen tropical forest (Figure 2b) is found at the South, nearby Cozumel, Kantunilkín and the surroundings of Felipe Carrillo Puerto. It is made-up by trees under $15 \mathrm{~m}$ high and the typical taxa are: tinto (Haematoxylom campechianum L.), pukté (Bucida buceras), chechem Metopium brownei (Jaca.) Urban) and sakpai (Byrsonima bucidaefolia Standl.) (INEGI, 1986).

The high sub-evergreen tropical forest (Figure 2b) is distributed in the South of the State; its tree stratum is over $30 \mathrm{~m}$ high and the following species outstand: caoba (Swietenia macrophylla), chicozapote (Manilkara zapota), pukte (Bucida buceras), ramón (Brosimun alicastrum), chaka (Bursera simaruba), pimienta (Pimenta dioica (L). Merrill), cedro rojo (Cedrela odorata) and caimito (Chrysophyllum mexicanum T. S. Brandegee ex Standl.) (INEGI, 1986).

\section{Determination of the project scope planning}

The project scope planning was defined for 30 years as it is the period in which the mahogany examples reach their economic rotation (García, 1998).

Source of information for the financial analysis

The technical coefficients of establishment and management, as well as their associated prices were supplied by the Unión de Indigenistas Mayas Plantadores Forestales Pa'Ka'Al Malo'O Cheo, S. A. de C. V. and Servicios Silvoagropecuarios S. A. (SESISA). The cutting and residual volume estimations were made through the following production and increment models fitted by García (1998):

$$
\begin{aligned}
& V T H=3.4664 E+0.6286 E^{2}-0.0120 E^{3} \\
& I C A=3.4664+1.2572 E-0.0360 E^{2} \\
& I M A=3.4664+0.6286 E-0.0120 E^{2}
\end{aligned}
$$

Where:

$$
\begin{aligned}
& V T H=\text { Total volumen per hectare }\left(\mathrm{m}^{3} \mathrm{ha}^{-1}\right) . \\
& I C A=\text { Current annual increment }\left(\mathrm{m}^{3} \mathrm{ha}^{-1} \text { year }{ }^{-1}\right) . \\
& I M A=\text { Average annual increment }\left(\mathrm{m}^{3} \mathrm{ha}^{-1} \text { year- }\right) . \\
& E \quad=\text { Age (years). }
\end{aligned}
$$

\section{Financial indicators}

They are measures of the profitability mostly used at present, since they consider the concept of "the value of money over time". They are not discriminant between them, as they can be used in a complimentary way to make decisions (Barbosa, 2007). The financial indicators that were used were the following: Present Net Value (PNV), Internal Return Rate (IRR), Benefit-Cost Ratio 
Retorno (TIR), Relación Beneficio-Costo (RB/C), Retorno Sobre la Inversión (RSI), Periodo de Retorno de la Inversión (PRI) e Indice de Deseabilidad (ID), los cuales sirven para la toma de decisiones sobre la rentabilidad esperada con la implementación del proyecto o, en su defecto, para decidir no invertir recursos financieros, cuando se esperan pérdidas. Las expresiones algebraicas son:

Valor Actual Neto:

$$
\text { VAN }=\sum_{i=0}^{n} \frac{B_{i}}{(1-i)^{i}}-\sum_{i=0}^{n} \frac{C_{i}}{(1-i)^{i}}
$$

Donde:

$$
\begin{aligned}
& B_{i}=\text { Beneficios en el período } i \\
& C_{i}=\text { Costos en el período } i \\
& i=\text { Tasa de descuento } \\
& i=\text { Período 0,1,2...n }
\end{aligned}
$$

Tasa Interna de Retorno (TIR):

$$
\sum_{i=0}^{n} \frac{B_{i}}{(1-i)^{i}}-\sum_{i=0}^{n} \frac{C_{i}}{(7-i)^{i}}=0
$$

La Relación Beneficio-Costo (RB/ C):

$$
B / C=\frac{\sum_{i=0}^{n} \frac{B_{i}}{(1-i)^{i}}}{\sum_{i=0}^{n} \frac{C_{i}}{(1-i)^{i}}}
$$

El Retorno sobre la inversión (RSI):

Donde:

$$
R S I=\frac{\sum_{i=0}^{n} \frac{F_{i}}{(1-i) i}}{F_{0}}=\frac{\text { VAN - Inversión }}{\text { Inversión }}
$$

$F_{i}=$ Flujo de fondos actualizados a la tasa de rendimiento requerida

$i=$ Periodos 1,2,3...n

$F_{0}=$ Valor actual de la inversión

$i=$ Tasa de descuento

Periodo de Retorno de la Inversión (PRI)

Es el período en el cual los beneficios de proyecto recuperan la inversión inicialmente efectuada Indice de Deseabilidad (ID):

$$
R S I=\frac{\sum_{i=0}^{n} F_{i}(1-i) i}{F_{0}}=\frac{\text { VAN }}{\text { Inversión }}
$$

(BCR), Return On Investment (ROI), Return On Investment Period or Payback Period (ROP) and Desirability Index (DI), which are useful for decision taking about the expected profit with the implementation of the project, or, otherwise, or to decide not to invest financial resources, when losses are expected. The algebraic expression is as follows:

Present Net Value (PNV):

$$
\text { VAN }=\sum_{i=0}^{n} \frac{B_{i}}{(1-i)^{i}}-\sum_{i=0}^{n} \frac{C_{i}}{(1-i)^{i}}
$$

Where:

$$
\begin{aligned}
& B_{i}=\text { Profits in the } i \text { period } \\
& C_{i}=\text { Costs in the } i \text { period } \\
& i=\text { Discount rate } \\
& i=0,1,2 \ldots \text { n periodo }
\end{aligned}
$$

Internal Return Rate (IRR):

$$
\sum_{i=0}^{n} \frac{B_{i}}{(7-i)^{i}}-\sum_{i=0}^{n} \frac{C_{i}}{(7-i)^{i}}=0
$$

Benefit-Cost Ratio (BCR):

$$
B / C=\frac{\sum_{i=0}^{n} B_{i}(7-i) i}{\sum_{i=0}^{n} C_{i}}
$$

Return On lnvestment (ROI):

Where:

$$
R S I=\frac{\sum_{i=0}^{n} \frac{F_{i}}{(1-i)^{i}}}{F_{0}}=\frac{\text { VAN }- \text { Inversion }}{\text { Inversion }}
$$

$F_{i}=$ Funding flux fitted to the required yield rate

$i=1,2,3 \ldots$, n periods

$F_{0}=$ Present Net Value (PNV)

$i=$ Discount rate

Return On Investment Period or Payback Period (ROIP):

In the period in which the profits of the project recover the investment initially made: Desirability Index (DI):

$$
R S I=\frac{\sum_{i=0}^{n} F_{i}(7-i) i}{F_{0}}=\frac{\text { VAN }}{\text { Inversin }}
$$




\section{Tasa de descuento}

La tasa de descuento real y libre de riesgo empleada correspondió a la utilizada por los Fideicomisos Instituidos en Relación a la Agricultura (FIRA) para el financiamiento de plantaciones forestales comerciales en el estado de Quintana Roo, los Certificados de la Tesorería de la Federación (CETES) a 28 días. Esta tasa es más baja que la que usa habitualmente el Banco Interamericano de Desarrollo (12\%), de acuerdo con De Rus et al. (2006).

\section{RESULTADOS Y DISCUSIÓN}

\section{Costos y beneficios}

A continuación se presenta el desglose de la inversión, de costos y beneficios unitarios proyectados para la elaboración del flujo de fondos del proyecto de establecimiento de una plantación forestal de caoba de 50 ha, la cual equivale al menos a $50 \%$ de una parcela ejidal en la región, además de ser una superficie susceptible de ser financiada por el PRODEPLAN.

\section{Costos de inversión}

Las inversiones en activo fijo están constituidas por los terrenos, memoria del proyecto, obras civiles (caminos), material vegetal y vehículos, mientras que el capital de trabajo se integra por la cantidad de recursos necesarios para financiar los desembolsos de las actividades en los primeros años y antes de tener ingresos intermedios o finales (Cuadro 2).

\section{Depreciación}

Se consideraron el valor inicial y el residual para los equipos, y se dejó fuera del análisis la depreciación para los activos fijos.

\section{Costos variables directos de establecimiento}

En algunos casos, una unidad puede ser utilizada en más de una hectárea, por lo que se determina el su costo unitario de una unidad del bien y posteriormente el costo atribuible o correspondiente a una hectárea. Estos costos se componen de:

- Herramientas y equipos menores.

- Insumos.

- Mano de obra directa.

\section{Discount Rate}

The real discount rate and free of risk that was used was the same as the one applied by Fideicomisos Instituidos en Relación a la Agricultura (FIRA) for funding commercial forest plantation in Quintana Roo State, by the Certificados de la Tesorería de la Federación (CETES) for 28 days. This is a lower rate than what regularly IDB uses (12\%), according to De Rus et al. (2006).

\section{RESULTS AND DISCUSSION}

\section{Costs and benefits}

Here is described the broken down information about investment, costs and unitary benefits planned for the organization of funding flux for the establishment project of a mahogany forest plantation of 50 ha, which is equivalent to at least $50 \%$ of an "ejido" lot in the region, which adds to the fact that it is an are a viable of sponsorship by PRODEPLAN.

\section{Investment Costs}

The fixed assets investments are made-up by lands, the memory of the project, civil constructions (roads), vegetal matter and vehicles, while working capital is formed by the amount of the necessary resources to finance the outlays of the activities of the first years and before having the in-between or final income (Table 2).

\section{Depreciation}

The initial and residual values for the equipments were considered and depreciation was left out of the fixed assets analysis.

\section{Establishment direct variable costs}

In some cases, one unit may be used in more than one hectare, which means that the unitary cost of the good is determined and afterwards the attributable cost of a hectare. These costs are formed by:

- Tools and small equipments

- Input

- Direct working force 
Cuadro 2. Costos de inversión inicial para el establecimiento de una hectárea de plantación comercial de Swietenia macrophylla (caoba).

Table 2. Initial investment costs for the establishment of a commercial plantation hectare of Swietenia macrophylla (mahogany).

\begin{tabular}{|c|c|c|c|c|c|c|c|}
\hline Inversión & Rubro & Unidad & $\begin{array}{c}\text { Cantidad } \\
\text { unidades ha-1 }\end{array}$ & $\begin{array}{l}\text { Costo unitario } \\
\text { (\$) }\end{array}$ & $\begin{array}{c}\text { Costo ha-1 } \\
\text { (\$) }\end{array}$ & $\begin{array}{l}\text { Vida útil } \\
\text { (años) }\end{array}$ & $\begin{array}{c}\text { Valor } \\
\text { Res ha' }\end{array}$ \\
\hline \multirow{6}{*}{$\begin{array}{l}\text { Activos } \\
\text { fijos }\end{array}$} & Terreno & ha & 1 & 2,000 & 2,000 & 30 & 2,000 \\
\hline & Plantas & Unidad & 1,111 & 1.70 & 1888.70 & 30 & 0 \\
\hline & Cercas & Cerca & $1 / 50$ & 18,100 & 362 & 30 & 362 \\
\hline & $\begin{array}{l}\text { Rehabilitación } \\
\text { Caminos }\end{array}$ & $\mathrm{km}$ & $1 / 50$ & 5,000 & 100 & 30 & 100 \\
\hline & Camioneta' & Unidad & $1 / 50$ & 60,000 & 1,200 & 4 & 120 \\
\hline & Motosierras $^{2}$ & Unidad & $1 / 50$ & 2,500 & $50^{3}$ & 4 & 5 \\
\hline \multirow{2}{*}{$\begin{array}{l}\text { Activos } \\
\text { diferidos }\end{array}$} & Proyecto & Unidad & $1 / 50$ & 50,000 & 1,000 & 30 & 0 \\
\hline & Capital trabajo & $\$ h^{-1}$ & 1 & 15,000 & 15,000 & 30 & 15,000 \\
\hline Total & & & & & $21,600.70$ & & $15,578.00$ \\
\hline
\end{tabular}

$1=$ Se comprarán camionetas en los años 0,10 y 20.

$1=$ Trucks will be bought in the 0,10 and 20 years.

2 = Se adquirirá una motosierra por cada 5 ha a los años 10, 15, 20, 25 y 30 .

$2=$ A power saw will be bought for every 5 ha at 10, 15, 20, 25 and 30 .

Valor Res ha ${ }^{-1}=$ Valor de rescate por ha.

Valor Res ha- = Rescue value per ha.

\section{Herramientas y Equipos menores}

Las herramientas menores o de consumo que se consideran en el proyecto son los que se presentan en el Cuadro 3.

\section{Tools and small equipments}

The small tools that are included in the project are shown in Table 3.

Cuadro 3. Herramientas para establecimiento y manejo de una hectárea de plantación comercial de Swietenia macrophylla. Table 3. Tools for the establishment and management of a hectare with a Swietenia macrophylla commercial plantation.

\begin{tabular}{|c|c|c|c|c|}
\hline Concepto & Unidad & Costo unitario $(\$)$ & Unidades (ha-1) & Costo total $(\$)$ \\
\hline Machete & Unidad & 40 & 2 & 80 \\
\hline Hachas & Unidad & 50 & 2 & 100 \\
\hline Limas & Paquete & 80 & 1 & 80 \\
\hline Talacho & Unidad & 40 & 2 & 80 \\
\hline Arañas & Unidad & 25 & 4 & 100 \\
\hline Azadón & Unidad & 30 & 2 & 60 \\
\hline Palas & Unidad & 40 & 2 & 80 \\
\hline Bomba aspersión & Unidad & 450 & 0.4 & 260 \\
\hline Alambre de púas & Rollo & 350 & 1 & 350 \\
\hline Postes de madera & Unidad & 10 & 12 & 120 \\
\hline TOTAL & & & 28 & 1,310 \\
\hline
\end{tabular}


Insumos

Los insumos se presentan en el Cuadro 4, los cuales se requieren para acelerar el crecimiento y mantener el control de plagas y enfermedades.
Inputs

Inputs are shown in Table 4, which are necessary to accelerate growth and keep under control pests and pathogens.

Cuadro 4. Insumos utilizados en el establecimiento y manejo de una hectárea de plantación comercial de Swietenia macrophylla. Table 4. Inputs used in the establishment and management of a hectare with a Swietenia macrophylla commercial plantation.

\begin{tabular}{lcccc}
\hline \multicolumn{1}{c}{ Concepto } & Unidad & Costo unitario (\$) & Unidades/ año & Costo total (\$) \\
\hline Fertilizante 18-46-00 (año 1-5) & $\mathrm{kg}$ & 8 & 50 & 400 \\
Fertilizante Groo-Green (año 1-2) & $\mathrm{kg}$ & 40 & 2 & 80 \\
B. bassiana (7 dosis/ año 1-5) & Dosis & 70 & 8 & 490 \\
Decís (5 dosis/ año 1-5) & $\mathrm{L}$ & 120 & 4 & 600 \\
Pasta bordelés (1 dosis/ año 1/3) & $\mathrm{kg}$ & 25 & 6 & 25 \\
Herbicidas (2 aplical año 2-5) & $\mathrm{kg}$ & 100 & 2 & 200 \\
\hline
\end{tabular}

Mano de obra directa

Son los operarios que ejecutan tareas generales y que realizarán los trabajos manuales desde la ubicación y preparación del sitio hasta la cosecha final (Cuadro 5).

\section{Direct working force}

This item refers to the workers that carry out general tasks, and that will do manual work, from site location and preparation to the final harvest (Table 5).

Cuadro 5. Mano de obra para el establecimiento y manejo de una hectárea de plantación comercial de Swietenia macrophylla. Table 5. Working force for the establishment and management of a hectare with a Swietenia macrophylla commercial plantation.

\begin{tabular}{|c|c|c|c|c|}
\hline Concepto & Unidad & $\begin{array}{c}\text { Costo unitario } \\
(\$)\end{array}$ & $\begin{array}{c}\text { Número de } \\
\text { unidades }\end{array}$ & Costo total $(\$)$ \\
\hline \multirow{9}{*}{$\begin{array}{l}\text { Preparación del sitio } \\
\text { Ubicación de terreno } \\
\text { Delimitación de terreno } \\
\text { Apertura de brechas } \\
\text { Corte de estacas } \\
\text { Trazado y estacado } \\
\text { Poceteado } \\
\text { Transporte de planta } \\
\text { Riego } \\
\text { Estiva } \\
\text { Transporte } \\
\text { Descarga } \\
\text { Establecimiento } \\
\text { Plantación } \\
\text { Replantación } \\
\text { Mantenimiento } \\
\text { Control de malezas } \\
\text { Deshierbes (2/ año/ } 5 \text { años) } \\
\text { Fertilización } \\
\text { Aplicación fertilización basal (2/ año/ } 4 \text { años) } \\
\text { Aplicación fertilizante foliar ( } 1 / \text { año/ } 2 \text { años) } \\
\text { Control biológico de plagas } \\
\text { Aplicación de Beauveria bassiana (8/ año/ } 5 \text { años) } \\
\text { Control químico de plagas } \\
\text { Decís (4 aplicaciones/ año/ } 5 \text { años) } \\
\text { Control manual de plagas } \\
\text { Podas de control (1/ año/ } 5 \text { años) } \\
\text { Protección } \\
\text { Apertura guardarrayas } \\
\text { Limpia anual guardarrayas }\end{array}$} & $\begin{array}{c}\text { Jornal } \\
\text { Jornal } \\
\text { Jornal } \\
\text { Jornal } \\
\text { Jornal } \\
\text { Jornal }\end{array}$ & $\begin{array}{l}80 \\
80 \\
80 \\
80 \\
80 \\
80\end{array}$ & $\begin{array}{l}2 \\
4 \\
11 \\
2 \\
5 \\
15\end{array}$ & $\begin{array}{c}160 \\
320 \\
880 \\
160 \\
400 \\
1,200\end{array}$ \\
\hline & $\begin{array}{l}\text { Jornal } \\
\text { Jornal } \\
\text { Flete } \\
\text { Jornal }\end{array}$ & $\begin{array}{c}80 \\
80 \\
900 \\
80\end{array}$ & $\begin{array}{l}1 \\
2 \\
1 \\
2\end{array}$ & $\begin{array}{l}80 \\
160 \\
900 \\
160\end{array}$ \\
\hline & $\begin{array}{l}\text { Jornal } \\
\text { Jornal }\end{array}$ & $\begin{array}{l}80 \\
80\end{array}$ & $\begin{array}{l}8 \\
1\end{array}$ & $\begin{array}{l}640 \\
80\end{array}$ \\
\hline & Jornal & 80 & 12 & 960 \\
\hline & $\begin{array}{l}\text { Jornal } \\
\text { Jornal }\end{array}$ & $\begin{array}{l}80 \\
80\end{array}$ & $\begin{array}{l}8 \\
2\end{array}$ & $\begin{array}{l}640 \\
160\end{array}$ \\
\hline & Jornal & 80 & 8 & 640 \\
\hline & Dosis & 80 & 4 & 320 \\
\hline & Jornal & 80 & 2 & 160 \\
\hline & $\begin{array}{l}\text { Jornal } \\
\text { Jornal }\end{array}$ & $\begin{array}{l}80 \\
80\end{array}$ & $\begin{array}{l}4 \\
2\end{array}$ & $\begin{array}{l}320 \\
160\end{array}$ \\
\hline
\end{tabular}

continúa Cuadro 5 
continuación Cuadro 5...

\begin{tabular}{|c|c|c|c|c|}
\hline Concepto & Unidad & $\begin{array}{c}\text { Costo unitario } \\
(\$)\end{array}$ & $\begin{array}{c}\text { Número de } \\
\text { unidades }\end{array}$ & Costo total $(\$)$ \\
\hline $\begin{array}{l}\text { Pozos para cercas } \\
\text { Posteado } \\
\text { Tendido de alambre } \\
\text { Silvicultura }\end{array}$ & $\begin{array}{l}\text { Jornal } \\
\text { Jornal } \\
\text { Jornal }\end{array}$ & $\begin{array}{l}80 \\
80 \\
80\end{array}$ & $\begin{array}{l}2 \\
1 \\
2\end{array}$ & $\begin{array}{l}160 \\
80 \\
160\end{array}$ \\
\hline $\begin{array}{l}\text { ler aclareo } 10 \text { años } \\
2^{\circ} \text { aclareo } 15 \text { años } \\
3^{\text {er }} \text { aclareo } 20 \text { años } \\
4^{\circ} \text { aclareo } 25 \text { años } \\
\text { Cosecha }\end{array}$ & $\begin{array}{l}\text { Jornal } \\
\text { Jornal } \\
\text { Jornal } \\
\text { Jornal }\end{array}$ & $\begin{array}{l}80 \\
80 \\
80 \\
80\end{array}$ & $\begin{array}{l}5 \\
8 \\
15 \\
20\end{array}$ & $\begin{array}{l}400 \\
640 \\
1,200 \\
1,600\end{array}$ \\
\hline $\begin{array}{l}\text { Derribo y troceo (año 30) } \\
\text { Arrime y carga (año 30) } \\
\text { Transporte (año 30) } \\
\text { Total de costos }\end{array}$ & $\begin{array}{l}\text { Jornal } \\
\text { Servicio } \\
\text { Flete }\end{array}$ & $\begin{array}{l}80 \\
900 \\
900\end{array}$ & $\begin{array}{c}40 \\
1 \\
1 \\
191\end{array}$ & $\begin{array}{l}3,200 \\
900 \\
900 \\
17,740\end{array}$ \\
\hline
\end{tabular}

Costos variables indirectos

Incluyen los sueldos a profesionales especializados que prestan los servicios de asesoría técnica para la planeación, el establecimiento, manejo y administración de la plantación, y que no se asocian específicamente a tareas físicas de producción (Cuadro 6).

Mano de obra indirecta

La contratación de servicios de asistencia técnica para la formulación del proyecto y para el manejo de la plantación a lo largo del ciclo de producción, así como de la administración de todos los recursos (Cuadro 6).

\section{Variable indirect costs}

They include the salaries of the experts that give technical advice for the planning, establishment, management and administration of the plantation, and that are not especially linked to the physical tasks involved in production (Table 6).

\section{Indirect working force}

It consists on contracting of technical support services for the formulation of the project and for the management of plantation through the production cycle, as well as the administration of all the resources involved (Table 6).

Cuadro 6. Mano de obra indirecta para establecimiento y manejo de una hectárea de plantación comercial de Swietenia macrophylla. Table 6. Indirect working force for the establishment and management of a hectare with a Swietenia macrophylla commercial plantation.

\begin{tabular}{llccc}
\hline \multicolumn{1}{c}{ Concepto } & Unidad & $\begin{array}{c}\text { Costo unitario } \\
\left(\$ \text { ha }^{-1} \text { mes }^{-11}\right)\end{array}$ & Número de unidades & Costo total $(\$)$ \\
\hline Asistencia técnica profesional & Consultoría & 50 & 1 & 50 \\
Administración & Administración & 50 & 1 & 50 \\
\hline
\end{tabular}

lngresos

Se consideró una secuela de cortas en la que se proponen aclareos a la edad de 10, 15, 20 y 25 años y una corta final a la edad de 30 años, tal como se observa en la Figura 3. Los volúmenes estimados de corte concuerdan con lo calculado por Synnott (2005) para plantaciones forestales de caoba de alto rendimiento en Campeche y Quintana Roo, que fueron de $300 \mathrm{~m}^{3} \mathrm{ha}^{-1}$.
Income

A cutting sequence was considered in which clearings at $10,15,20$ and 25 years are proposed and a final cut at 30 years old, as it is observed in Figure 3. The estimated cutting volumes agree with those calculated by Synnott (2005) for high yield mahogany forest plantations in Campeche and Quintana Roo States, which were of $300 \mathrm{~m}^{3} \mathrm{ha}^{-1}$. 


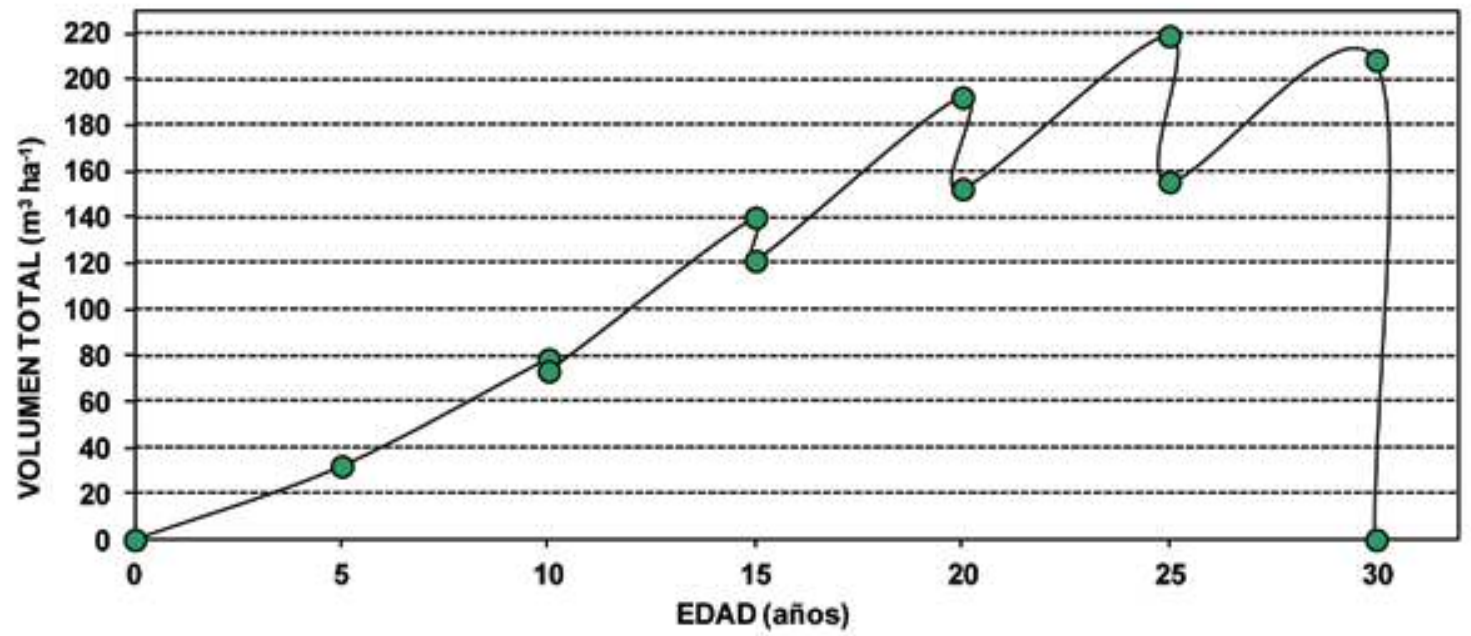

Figura 3. Secuela de cortas para plantaciones forestales comerciales de Swietenia macrophylla.

Figure 3. Cutting sequence for Swietenia macrophylla commercial plantations.

Para determinar los ingresos, se multiplicó la cantidad de madera que se estima obtener en el periodo dado, por el precio unitario del $\mathrm{m}^{3}$ a precio de mercado (Cuadro 7).
To determine income, the amount of wood that is estimated to get for a given time was multiplied by the unitary price of $\mathrm{m}^{3}$ at market price (Table 7).

Cuadro 7. Ingresos en el establecimiento y manejo de una hectárea de plantación comercial de Swietenia macrophylla. Table 7. Income in the establishment and management of a hectare with a Swietenia macrophylla commercial plantation.

\begin{tabular}{cccccc}
\hline Año & Actividad & $\begin{array}{c}\text { Existencias } \\
\left(\mathrm{m}^{3} \mathrm{ha}^{-1}\right)\end{array}$ & $\begin{array}{c}\text { Volumen de } \\
\text { corte }\left(\mathrm{m}^{3} \mathrm{ha}^{-1}\right)\end{array}$ & $\begin{array}{c}\text { Precio de venta } \\
\left(\$ \mathrm{~m}^{3}\right)\end{array}$ & $\begin{array}{c}\text { Ingreso } \\
(\$)\end{array}$ \\
\hline 5 & -- & 31.9657 & 0.00 & 0.00 & 0.00 \\
10 & ler aclareo & 78.5186 & 5.18 & 1,000 & $5,180.00$ \\
15 & $2^{-0}$ aclareo & 139.9929 & 18.81 & 2,000 & $37,628.20$ \\
20 & 3er aclareo & 192.2658 & 39.85 & 3,000 & $119,556.30$ \\
25 & $4^{-0}$ aclareo & 218.9307 & 63.41 & 3,000 & $190,227.30$ \\
30 & Corta final & 208.4686 & 208.47 & 3,000 & $625,405.80$ \\
Total & & & 335.72 & & $977,997.60$ \\
\hline
\end{tabular}

\section{Subsidios}

Las plantaciones forestales son de interés público, por lo tanto es de interés social que el gobierno aporte recursos dentro de diferentes esquemas de financiamiento, para aligerar el costo financiero de los proyectos y con ello darles viabilidad económica, sino para el gobierno, sí para el productor (Del Castillo, 1996).

Aquellas plantaciones que cumplan con los requisitos de las bases del PRODEPLAN, son elegibles para recibir los subsidios del programa, que ascienden a un monto de $\$ 7,000$ por hectárea, los cuales, se propone que se soliciten en tres ministraciones, de $\$ 3,500.00$ para el segundo año del establecimiento y $\$ 1,750.00$ en los años tres y cuatro.
Subsidies

Forest plantations are of public interest, thus, it is of social concern that the government provides resources within different financial schemes to make lighter the financial cost of the projects and in this way, gives them economic viability, if not to the government, to the producer (Del Castillo, 1996).

Those plantations that satisfy the requirements of PRODEPLAN are eligible to receive the subsidies of the program, that are up to $\$ 7,000$ per hectare, which is suggested that they be demanded in three applications, of $\$ 3,500.00$ for the second year of the establishment and $\$ 1,750.00$ in the years 3 and 4 . 


\section{Análisis financiero}

La estructura de costos y beneficios actualizados de un proyecto consisten en una sucesión de flujos monetarios deflactados positivos (beneficios) y negativos (costos) que se suceden a partir de una inversión inicial realizada en el período t=0 (De Rus et al., 2006).

En la Figura 4 se observa que los costos se concentran, principalmente, en los cinco primeros años, sobre todo por conceptos de inversión, establecimiento, control de plagas y mantenimiento. Por su parte, los primeros beneficios importantes se obtienen a partir del año 15, cuando se generan ingresos derivados de la venta de madera producto de aclareos.

En los años subsiguientes, los costos de mantenimiento, protección o labores silvícolas son mínimos, excepto el último. Aunque este es salvable, ya que en este momento se tiene ahí el ingreso principal. Los beneficios económicos se generan a partir del décimo año, pero es desde el año 15 cuando se tendrá mayor seguridad de colocar la madera en el mercado, y en consecuencia de obtener cantidades considerables de recursos económicos.

De acuerdo con los indicadores determinados, la actividad de inversión en plantaciones forestales con fines comerciales es rentable y viable.

El Valor Presente Neto (VPN) de 162,344.2 (mayor de cero) resultó al descontar los flujos de fondos a la tasa de retorno libre de riesgo de 6.07\% (Valor de CETES de 2005), por lo tanto el proyecto es rentable, desde el punto de vista financiero.

\section{Financial analysis}

The structure of current costs and benefits of a project consists of a succession of positive (benefits) or negative (costs) delated monetary flow that follows one another from the initial investment at the $\mathrm{t}=\mathrm{O}$ period (De Rus et al., 2006).

In Figure 4 is observed that costs concentrate, mainly, in the first 5 years, particularly in investment, establishment, plague control and maintenance concepts. On the other hand, the first important profits are obtained from the $15^{\text {th }}$ year onwards, when incomes result from selling the wood obtained from clear-cuttings.

In the following years, maintenance, protection or forestry labor costs are minimal, except for the last one, though it is manageable since in this moment there is the main income. The economic benefits start in the $10^{\text {th }}$ year, but it is in the $15^{\text {th }}$ when it is safer to place the wood into the market and, consequently, to get important financial resources.

According to the determined indicators, the investment activity in forest plantations with commercial endings is profitable and viable.

The Net Present Value (NPV) of 162, 344.2 (>0) was the result of discounting the cash flow from the risk-free rate of return of $6.07 \%$ (CETES value of 2005), thus, the project is profitable from a financial point of view.

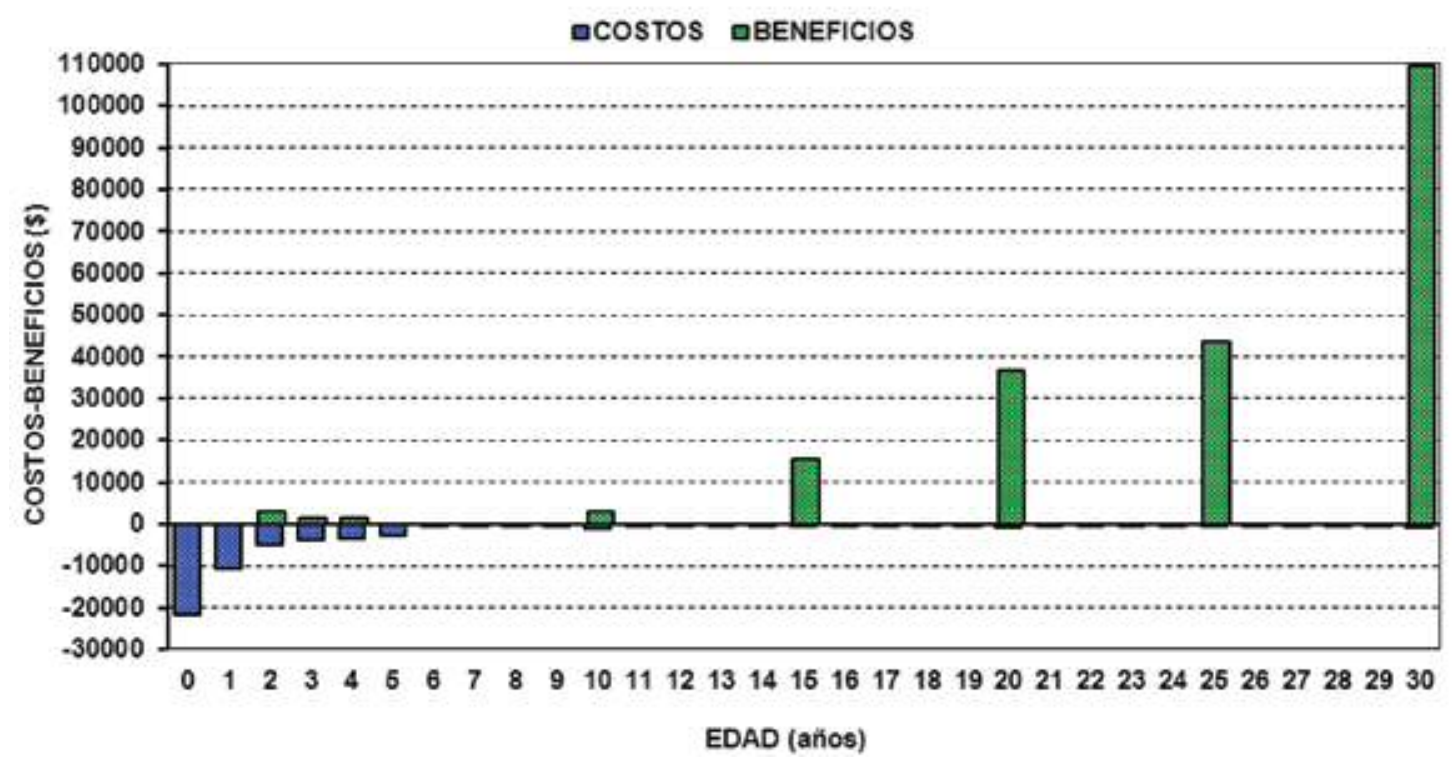

Figura 4. Estructura de beneficios y costos deflactados en plantaciones forestales comerciales de Swietenia macroplhylla. Figure 4. Structure of deflected benefits and costs in commercial forest plantations of Swietenia macrophylla. 
La Tasa Interna de Retorno (TIR) de 13.37\% corresponde a la tasa de descuento, que hace al Valor Actual Neto (VAN) de los flujos de fondos igual a cero, por lo que es más grande al costo de oportunidad de $6.07 \%$. La TIR indica la eficiencia porcentual del proyecto por cada peso invertido, en la cual existe un diferencial superior al doble; por lo tanto, la inversión es muy atractiva. Lo anterior coincide con los registros de Synnott (2005), quien consignó valores mayores a $9 \%$ para este indicador, con tasas de descuento del 10\% para plantaciones establecidas en la región de Sian Ka'an en Quintana Roo y Calakmul en Campeche. El gobierno del estado de Jalisco estimó una TIR de 12.6 a 20.2 y una Relación Beneficio- Costo (RB/C) de 1.56 a 3.5 para plantaciones forestales (Cuadro 7); la FUMIAF (2005) considera una TIR de 29\%, con una tasa de descuento de $9.23 \%$, con lo que concluye, en forma contundente, que el negocio de las plantaciones forestales comerciales de caoba es rentable.

La Relación Beneficio-Costo (RB/C) fue de 4.10, es decir aceptable, de acuerdo con el criterio de que una inversión es viable, si el valor de la relación beneficio - costo es superior a 1.0. Esta cifra es muy parecida al 4.39 para producción de madera aserrada y al de 3.10 para madera en rollo citados en el plan de negocios para el cultivo comercial de caoba elaborado por la FUMIAF (2005).

En el Cuadro 8 se observa que entre las actividades primarias, las forestales son las que a mediano plazo generan los mejores beneficios económicos en el estado de Jalisco.
The Internal Return Rate (IRR) of $13.37 \%$ belongs to the discount rate, that makes the Net Present Value (NPV) of cash flow $=0$, which means that it is higher than the opportunity cost of $6.07 \%$. The IRR indicates the per cent efficiency of the project by each invested peso, in which there is a difference over the double; thus, the investment is very attractive. The former is coincidental with the records of Synnott (2005), who stated that values over $9 \%$ for this indicator, with discount rates of $10 \%$ for established plantations in Sian Ka'an in the State of Quintana Roo and Calakmul in the State of Campeche. The government of the state of Jalisco estimated an IRR of 12.6 to 20.2 and a Benefit-Cost Ratio (BCR) of 1.56 to 3.5 for forest plantations (Table 7); FUMIAF (2005) considers an IRR of $29 \%$, with a discount rate of 9.23 , with which it concludes in a convincing way, that the business of commercial forest plantations is profitable.

The Benefit-Cost Ratio (BCR) was 4.10, that is, acceptable, according to the criterion that an investment is viable, if the Benefit-Cost Ratio (BCR) is above 1.0. This number is similar to 4.39 for lumber production and 3.10 for roundwood as stated in the business plan for the commercial cultivation of mahogany of FUMIAF (2005).

In Table 8 is observed that among the primary activities, the forest-related produce the highest economic benefits in Jalisco State at medium-term.

Cuadro 8. Indicadores financieros para actividades primarias en el estado de Jalisco.

Table 8. Financial indicators for primary activities in the State of Jalisco.

\begin{tabular}{|c|c|c|}
\hline Agricultura & Ganadería extensiva & Plantaciones forestales \\
\hline Cultivo de Agave & Ganado vacuno & Plantaciones de eucalipto \\
\hline Clima templado & Clima templado & Clima templado \\
\hline$T \mathbb{R}=4.68$ (Eventual & $T \mathbb{R}=-1.0$ & $T \mathbb{R}=12.6$ \\
\hline$B / C=0.50$ & $B / C=0.63$ & $B / C=1.56$ \\
\hline Cultivo de maíz o frijol & Ganado vacuno & Plantaciones de eucalipto \\
\hline Clima cálido & Clima cálido & Clima cálido \\
\hline$T R=1.2$ & $T R=1.0$ & $T \mathbb{R}=18.2$ \\
\hline$B / C=0.96$ & $B / C=0.85$ & $B / C=2.10$ \\
\hline Cultivo de sandía & Ganado vacuno & Plantaciones de cedro rojo, Caoba o teca \\
\hline Clima cálido & Clima cálido & Clima cálido \\
\hline$T \mathbb{R}=3.6$ & $B / C=1.0$ & $T I R=20.2$ \\
\hline$B / C=1.2$ & $B / C=0.85$ & $B / C=3.5$ \\
\hline
\end{tabular}


El Retorno Sobre la Inversión (RSI) de 8.53, como resultado del cociente entre el flujo de fondos actualizados a la tasa de $6.07 \%$ y el valor actual de la inversión es mayor que 1.0, por lo que se considera que el proyecto analizado es viable.

El Periodo de Recuperación de la Inversión (PRI) en el cual los beneficios de flujos de fondos recuperan la inversión, inicialmente efectuada, ocurre a los 25 años, edad en la que se practica el cuarto aclareo y se tiene un fuerte ingreso por la venta de la madera en rollo.

El Índice de Deseabilidad (ID) se estimó en 7.53, por lo que el criterio de decisión consistirá en efectuar las inversiones cuyo índice de deseabilidad (ID) sea superior, pero que maximicen el VAN.

\section{Análisis de sensibilidad}

En la Figura 5 a se muestra que al disminuir la tasa de descuento, el VAN se incremente, lo cual indica los beneficios que recibiría el proyecto mediante la consecución de recursos a menor costo (tasa de descuento). Por ejemplo, si la tasa de descuento es del 5\%, se obtendría un VAN de 223,522.5 y una $\mathrm{RB} / \mathrm{C}$ de 5.14, con el consecuente aumento en la rentabilidad del proyecto.

Al crecer la tasa de descuento, llega un momento en la cual el VAN = 0 y la TIR ocurre a una tasa de $13.37 \%$, a partir de ese punto el VAN será menor que cero, entonces, la implementación del proyecto le generaría pérdidas al inversionista (Figura 5a).

Cuando la tasa de descuento es menor y los precios de venta de la madera en rollo aumentan, los beneficios se incrementan en gran medida, lo cual indica que si todas las estimaciones de los volúmenes de madera, los costos de producción

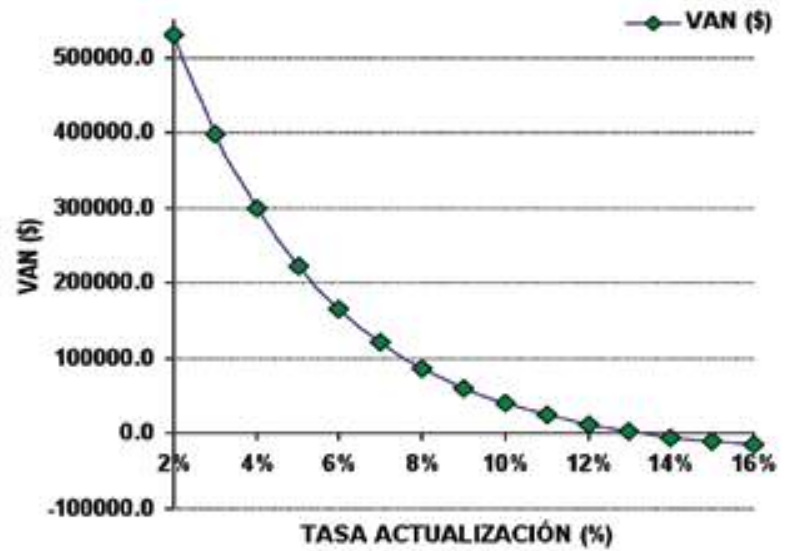

As the Return On Investment (RSI) is 8.53 as a result of the quotient between the cash flow adjusted to the $6.07 \%$ rate and that the present investment value is over 1.0, the analyzed proyect is viable.

The Return on Investment Period or Payback Period (ROIP) in which the benefits of cash flow recover the investment initially made, takes place in 25 years, age in which the fourth clear-cut is made and a great income is produced from selling roundwood.

The Desirability Index (ID) is estimated in 7.53, which means that the decision criterion will consist in making investment in which the Desirability Index (DI) is greater, but that they maximize the Present Net Value (PNV).

\section{Sensibility analysis}

In Figure 5a is shown that when the discount rate diminishes, PNV increases, which indicates the benefits that the project would receive by the achievement of resources at a lower cost (discount rate). For example, if the discount rate is $5 \%$, a PNV of 223,522.5 and a 5.14 Benefit-Cost Ratio (BCR) would be obtained, with the resulting increment of the profitability of the project.

When the discount rate increases, there is a time when $P N V=O$ and the $\mathbb{R R}$ occurs at a $13.37 \%$ rate; from then on, PNV will be smaller than zero, thus, the implementation of the project would generate losses to the investor (Figure 5a).

When the discount rate is small and the sale prices of roundwood increase, the benefits increase greatly, which means that if all the estimations of Wood volumes, production costs and sale prices are kept the same, the minimal sale prices are those shown in Figure 5b.

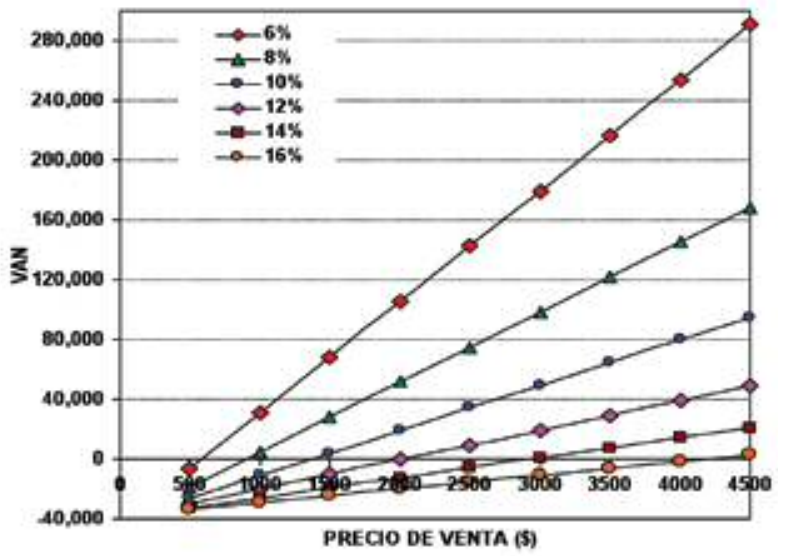

Figura 5. Variación del VAN en función de la tasa de descuento (a) y de la tasa de descuento y precios de venta (b) en plantaciones forestales de Swietenia macrophylla.

Figure 5. Variation of PNV in regard to the discount rate (a) and the discount rate and sale prices (b) in forest plantations of Swietenia macrophylla. costs and sale prices are kept the same, the minimal sale prices are those shown in Figure 5b. 
y los precios de venta se mantienen, los precios mínimos de venta son los que se presentan en la Figura $5 b$.
In regard to $\mathrm{BCR}, \mathrm{ROI}$ and $\mathrm{Dl}$, at any rate above $13.4 \%$, the project becomes unviable, as shown in Figure 6.

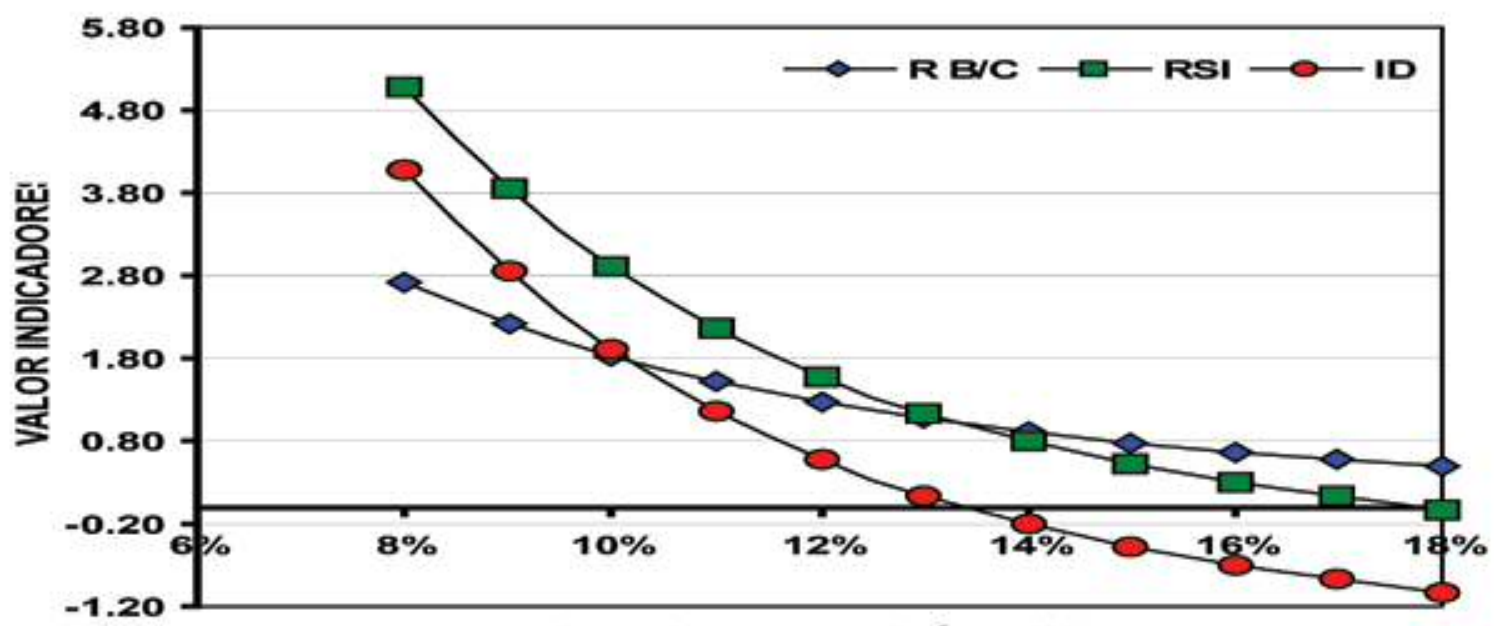

TASA ACTUALIZACIÓNn (\%)

Figura 6 Variación de indicadores financieros ante variación de i en plantaciones forestales de Swietenia macrophylla. Figure 6. Variation of financial indicators in face of the variation of $i$ in forest plantations of Swietenia macrophylla.

Respecto de la RB/ C, RSI e ID, a cualquier tasa superior a $13.4 \%$, el proyecto deja de ser viable, tal como se muestra en la Figura 6.

\section{CONCLUSIONES}

El análisis de la rentabilidad del proyecto muestra indicadores financieros positivos, aún si se consideran el largo periodo de su maduración, por lo que las plantaciones forestales comerciales de caoba son una buena opción de inversión en el estado de Quintana Roo.

El análisis de sensibilidad muestra hasta qué niveles se puede variar la tasa de actualización o precios de venta de la madera en el proyecto y que este siga siendo rentable.

Dados los indicadores financieros obtenidos, se recomienda la inclusión de las plantaciones forestales de caoba en los esquemas de financiamiento del sector y el apoyo con subsidios por parte de los gobiernos federal y estatal, para aligerar el costo financiero y darles viabilidad económica. ()

\section{REFERENCIAS}

Barbosa G., G. 2007. Plan I. Gerencia y mercadeo. Formulación y evaluación de proyectos de inversión. In: Memoria del Curso Formulación y evaluación de proyectos de inversión. FIRA. Chetumal, O. Roo. Agosto de 2007. 37 p.

\section{CONCLUSIONS}

The analysis of profitability of the Project shows positive financial indicators, even if it is considered the long maturation period, which makes the commercial forest plantations of mahogany a good investment option in the State of Quintana Roo.

The sensibility analysis shows the level at which the actualization rate or sale prices of wood in the project can vary and keep itself profitable.

From the obtained financial indicators, it is advised to include mahogany forest plantations in the sponsoring schemes of the sector and to support them with subsidies from the federal and state governments, in order to lighten their financial cost and give them economic viability.

End of the English version

Banco Nacional de Obrasy Servicios Públicos (BANOBRAS). 2005. Lineamientos generales para la presentación de estudios de evaluación económica y financiera, sobre proyectos para la creación de recintos fiscalizados estratégicos. 57 p. http://www.banobras.gob.mx/NR/ rdonlyres/F668EB9C-479D-4206-9532-33E5BA02470B/1567/ LineamientosRecintosFiscalizadosEstrategicos21Agos.pdf. (febrero de 2009).

Banco Interamericano de Desarrollo (BID). 2005. Estudio sobre inversión directo en negocios forestales sostenibles (Proyecto atn/np-8323-rs): índice de atracción a la inversión forestal (iaif). Informe Final - Rev. O1. Curitiba, Brasil. 224 p. http://www.incae.edu/ES/clacds/indicede-atraccion-a-la-inversion-forestal/pdfs/iaif-completo.pdf. (febrero de 2009). 
Comisión Forestal del Estado de Michoacán (COFOM). 2003. Programa de Plantaciones Forestales de Michoacán. Bosques y Selvas de Michoacán. Año 1. Vol. 1 Época 1. №. 3. Morelia, Mich. pp. 6-7. http://cofom.michoacan.gob.mx/prodeplan.htm. (enero de 2009).

Del Castillo C., P. E. 1996. Evaluación financiera de plantaciones forestales comerciales. Revista Madera y Bosques 2(1):3-8.

De Rus M., G., O. Betancor C. y J. Campos M. 2006. Evaluación económica de proyectos de transporte. Banco Interamericano de Desarrollo. Washington, DC. USA. $188 \mathrm{p}$.

Fundación Mexicana para la Investigación Agropecuaria y Forestal, A.C. (FUMIAF) 2005a. Cultivo de especie forestal comercial caoba (Swietenia macrophylla King) en México: Plan de negocios. México, D. F. México. pp. 56.

Fundación Mexicana para la Investigación Agropecuaria y Forestal, A.C. (FUMIAF) 2005b. Cultivo de especie forestal comercial cedro rojo (Cedrela odorata L.) en México: Plan de negocios. México, D. F. México. pp. 58.

García C., X. 1998. Predicción del rendimiento de Swietenia macrophylla King (caoba) en plantaciones forestales. Tesis de Maestría. Colegio de Postgraduados. Montecillo, Edo. de Méx. México. 114 p.

Graterol R., M. L. 2008. Proyecto de inversión. Instituto Universitario de Tecnología de Administración Industrial. http://www.monografias.com/usuario/ perfiles/marialuisagraterolrodriguez/monografias. Aragua, Venezuela. (julio de 2009).

Instituto Nacional de Estadística, Geografía e Informática (INEGI). 1986. Anuario estadístico del estado de Quintana Roo. México, D. F. México. 728 p.
Inteligencia Tecnológica en Software, S. de R. L. Mi. 2007. Intecplan ${ }^{\circledR} 3$ vi.O: software para formulación de proyectos. http://www.intecplan.com. $\mathrm{mx}$. (marzo de 2009).

McGaughey, S. E. 2007. Financiación internacional de la silvicultura. Depósito de documentos de la FAO. Departamento de Montes. http://www. fao.org/docrep/r6560S/r6560s02.htm\#TopOfPage. (marzo de 2009).

Monreal R., B. 2007. La producción de madera de plantaciones forestales será de 275 mil metros cúbicos el 2006. Revista Forestal XXI. 9(2): 10- 12.

Noguez H., A. 2010. El sur de Jalisco es ejemplo en plantaciones forestales comerciales. http://www.portalforestal.com/informacion/ 1234-elsur-de-jalisco-es-ejemplo-en-plantaciones-forestales-comerciales. html. (junio de 2010).

Programa de Desarrollo Forestal de Jalisco (PRODEFO). 2000. Manual de silvicultura y manejo de bosques templados. Ciclo económico forestal. Documento Técnico No. 22. Guadalajara, Jal. México. 135 p.

Secretaría de Agricultura y Recursos Hidráulicos (SARH). 1981. Marco de referencia para la planeación y evaluación de la investigación agrícola en el estado de Quintana Roo. Instituto Nacional de Investigaciones Agrícolas. Campo Agrícola Experimental Chetumal. Chetumal, O. Roo. México. 57 p.

Synnott., T. J. 2005. Evaluación de las Plantaciones Forestales en el Área de Sian Ka'an - Calakmul en los estados de Quintana Roo y Campeche. Informe Final. Estudios Forestales Synnott S.C. Saltillo, Coah. México. 66 p.

Universidad Veracruzana (UV). 2007. Evaluación de las actividades productivas en el sector rural. www.uv.mex/iiescala/plan2000/ED5.htm. (febrero de 2009). 


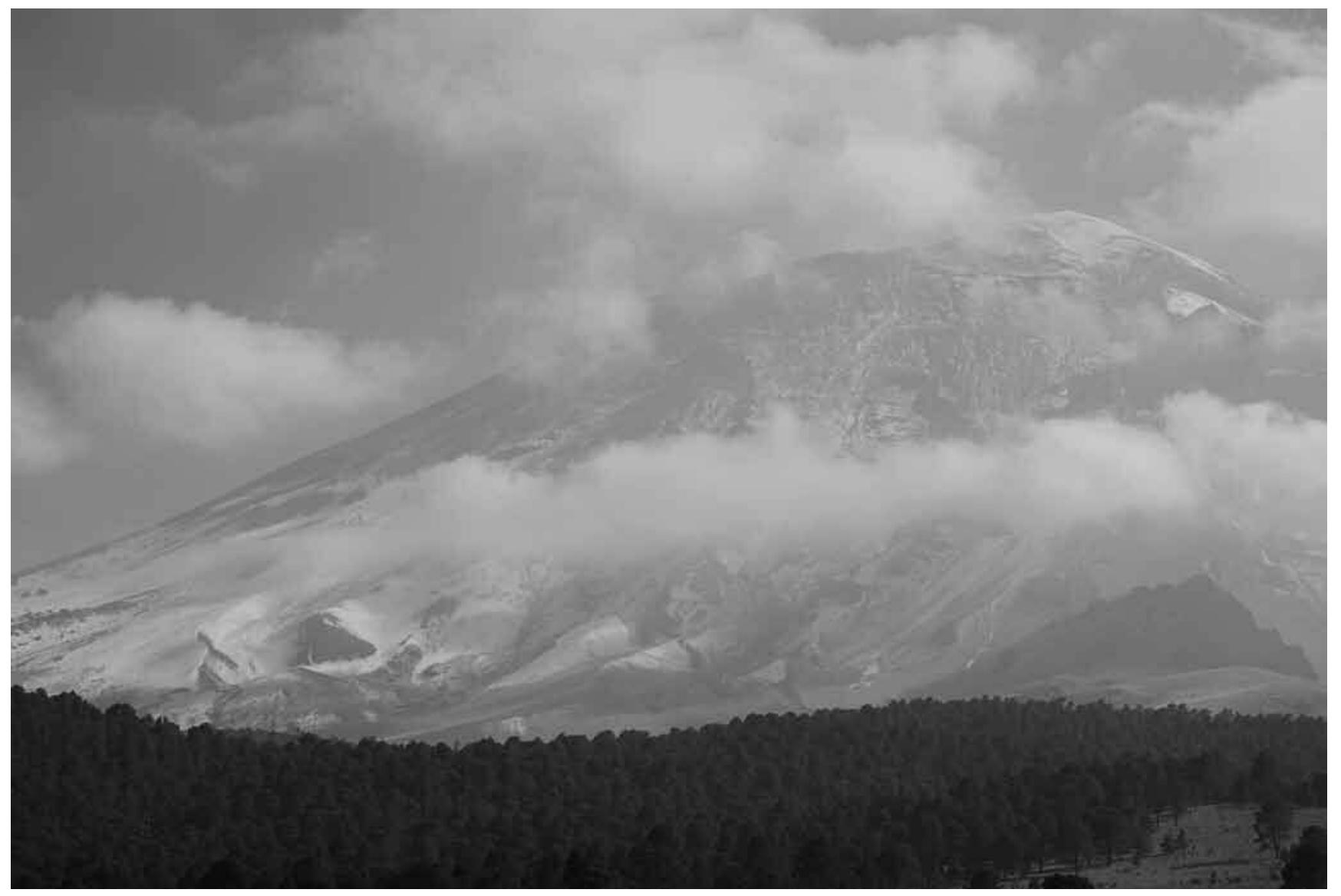

Leonardo Atilano Ponce (2012). Al pie del Volcán, Parque Nacional Iztaccihuatl-Popocatépetl. 